\title{
Akciğer Kanserinin ve Kemoterapinin Uyku ve Yașam Kalitesi Üzerine Etkisi
}

\section{The Effect of Lung Cancer and Chemotherapy on Sleep Quality and Quality of Life}

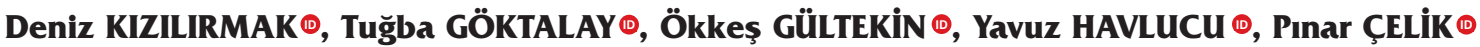

Cite as: Kızılırmak D, Göktalay T, Gültekin Ö, Havlucu Y, Çelik P. Akciğer kanserinin ve kemoterapinin uyku ve yaşam kalitesi üzerine etkisi. İzmir Göğüs Hastanesi Dergisi. 2021;35(2):82-90.

öz

Amaç: Akciğer kanseri, hem lokal hem de sistemik etkilerine bağlı olarak uyku ve yașam kalitelerini etkilemektedir. Akciğer kanseri tedavisinde sıkıkla kullanılan kemoterapi ise; hastalık yanıtı, kemoterapi yan etkileri, kemoterapötik ajana bağlı sistemik etkiler ve immünsupresyon sonucu gelișen komplikasyonlar nedenleriyle uyku ve yaşam kalitelerini etkileyebilmektedir. Bu çalışmada, lokal ileri ve metastatik evre akciğer kanserli hastalarda, kemoterapinin erken dönemde uyku ve yașam kaliteleri üzerine etkisi araştıııldı.

Yöntem: Lokal ileri ve metastatik evre akciğer kanseri tanısı ile tek bașına kemoterapi alan hastalara tanı anında ve 3. kür kemoterapi sonrası uyku kalitesi ve yaşam kalitesini değerlendirebilmek için Pittsburg Uyku Kalitesi İndeksi ve EORTC QLQ-C30 Kanser Hastalarının Yaşam Kalitesi Ölçeği uygulandı. Hastaların ortalama yașı $61.85 ' t i( \pm 6.80)$ ve $\% 89.8$ 'i erkekti. Tanı anında hastaların $\% 69,5$ 'i kötü uyku kalitesine sahipti. Fonksiyonel parametreler açısından en çok fiziksel işlev etkilenmiş olarak saptandı. Yaşam kalitesini en çok etkileyen semptomlar hâlsizlik ve dispneydi.

Bulgular: Akciğer kanserli hastalarda tanı sırasında uyku ve yașam kaliteleri arasında belirgin korelasyon gözlendi, ancak kemoterapi sonrası erken dönemde uyku kalitesinde anlamlı değişiklik saptanmadı. Yaşam kalitesi skorları değerlendirildiğinde kemoterapi sonrası sosyal işlevlerde ve bulantı semptomunda istatistiksel olarak zayıf; hâlsizlik semptomunda istatistiksel olarak belirgin kötüleșme vardı. Diğer yașam kalitesi parametreleri genel olarak tedavi öncesi ile benzerdi.

Sonuç: Sonuç olarak, akciğer kanserli hastalarda kemoterapi erken dönemde hastaların uyku kalitesinde belirgin bir değişiklik yapmıyorken yașam kalitesini olumsuz yönde etkileyebilmektedir.

Anahtar kelimeler: Uyku kalitesi, yaşam kalitesi, akciğer kanseri, kemoterapi

\section{ABSTRACT}

Objective: Lung cancer affects the quality of sleep and life depending on both local and systemic impacts. Chemotherapy that is frequently used in the treatment of lung cancer can affect quality of sleep and life due to disease response, side effects of chemotherapy, systemic effects due to chemotherapeutic agents and complications of immunosuppression. The sleep and life quality levels of patients with locally advanced and metastatic stage lung cancer and the effect of chemotherapy on sleep and quality of life in this patient group were investigated in this study.

Method: The Pittsburg Sleep Quality Index and the EORTC QLQ-C30 Cancer Patients' Quality of Life Scale were applied to the patients who received chemotherapy alone with diagnosis of locally advanced and metastatic stage lung cancer at the time of diagnosis and after the third course of chemotherapy to evaluate sleep quality and quality of life. The mean age of the patients was $61.85( \pm 6.80)$ and $89.8 \%$ of them were male. $69.5 \%$ of all patients had poor sleep quality at the time of diagnosis. Physical function was found to be affected the most in terms of functional parameters. The symptoms that most affected the quality of life were fatigue and dyspnea.

Results: A significant correlation was observed between sleep quality and quality of life at the time of diagnosis in patients with lung cancer, but no significant change was found in sleep quality in the early period after chemotherapy. There was a statistically weak worsening in social functions and nausea symptom after chemotherapy and a statistically significant worsening in the malaise symptom when the quality of life scores were evaluated. Other quality of life parameters were generally similar to those before treatment.

Conclusion: In conclusion, while chemotherapy does not make a significant change in the sleep quality of patients in the early period in patients with lung cancer, it may negatively affect the quality of life.

Keywords: Sleep quality, quality of life, lung cancer, chemotherapy
Received/Geliș: 11.02 .2021

Accepted/Kabul: 14.06.2021

Published Online/Online Yayın: 06.08.2021

Corresponding author/Sorumlu yazar: D. Kızılırmak ORCID: 0000-0001-9445-1598 Manisa Celal Bayar Üniversitesi, Hafsa Sultan Hastanesi, Göğüs Hastalıkları Kliniği,

8. Kat. Uncubozköy Manisa - Türkiye

dr_dkizilirmak@yahoo.com

T. Göktalay

ORCID: 0000-0002-1757-994X

Ö. Gültekin

ORCID: 0000-0001-9753-8744

Y. Havlucu

ORCID: 0000-0002-7441-288X

P. Celik

ORCID: 0000-0003-1015-8189

Manisa Celal Bayar Üniversitesi Tıp Fakültesi,

Göğüs Hastalıkları Anabilim Dalı

Manisa, Türkiye

() Telif hakkı İzmir Göğüs Hastanesi'ne aittir. Logos Tıp Yayıncllık tarafından yayınlanmaktadır.

Bu dergide yayınlanan bütün makaleler Creative Commons 4.0 Uluslararası Lisansı (CC BY) ile lisanslanmıștır. 


\section{Giriș}

Sistemik bir hastalık olan kanser hem tümörün lokalizasyonuna bağlı mekanik etkilerine hem de tümör hücrelerinden salınan mediatörlere ve tümör hücrelerinin hızlı metabolizmasına bağlı olarak hastaların yaşam ve uyku kalitelerini etkilemektedir. Uyku bozuklukları normal popülasyonda \%5-35 arasında iken, kanser hastalarında \%30-50 oranında, ileri evre kanser hastalarında ise daha sık olarak görülmektedir (1). Kanser tedavisinde kullanılan kemoterapötik ilaçların sitotoksite özelliklerine ve yan etkilerine bağlı olarak da hastaların uyku ve yaşam kaliteleri bozulabilmektedir ${ }^{(2)}$.

Akciğer kanseri; erken tanısı zor, sıklıkla geç tanı alan ve tanı anında uzak metasaz ile karşımıza çıkan bir kanser türüdür. Tümörün lokalizasyonu kaynaklı olarak kemik metastazı, sinirsel yapıların, pariyetal plevranın ve gögüs duvarının tümör tarafından invazyonu hastalarda ağrıya neden olabilir. Ayrıca nörolojik tutuluma bağlı hastalarda yürüyememe, denge bozukluğu gelişebilir. Beyin metastazı olan hastalarda bilinç bozukluğu, denge bozukluğu, baş ağrısı gibi semptomlar yaşam ve uyku kalitelerini bozabilirler. Bunların yanı sıra tümörün sistemik etkilerine bağlı olarak kilo kaybı, kaşeksi, iştahsızlık, ateş, bulantı-kusma, hâlsizlik gibi semptomlar da yaşam ve uyku kalitelerini olumsuz etkileyen faktörlerdir ${ }^{(1,3)}$.

İleri evre kanser hastalarında verilen kemoterapinin hastalarda yaşam süresini uzattığı bilinmektedir. Kemoterapi ile birlikte tümör boyutlarında küçülme, metastazlarda gerileme, tümörün bası bulgularında ve sistemik etkilerinde gerileme ve bu etkilerle birlikte hastaların yaşam kalitelerindeiyileşmebeklenmektedir. Kemoterapötik ajanlara bağlı yan etkiler, ilaç toksisiteleri, kemik iliği baskılanması, fırsatçı infeksiyonlar gibi nedenler ise yaşam kalitesini olumsuz etkileyen faktörlerdir ${ }^{(4)}$.

Bu çalışmanın ön sonuçları olarak lokal ileri ve metastatik evre akciğer kanserli hastaların yaşam ve uyku kalitelerinin tanı anındaki durumunun araştırılması amaçlandı. Tanı anındaki durumun saptanmasının yanı sıra bu hasta grubunda kemoterapinin ve kemoterapiye yanıtın erken dönemde yaşam ve uyku kalitelerini nasıl etkileyebileceğinin araştırılması da amaçlandı.

\section{GEREÇ ve YÖNTEM}

Hastanemiz Torasik Onkoloji Polikliniğinde lokal ileri ve metastatik evre akciğer kanseri tanıII hastalardan 16.10.2019-14.08.2020 tarihleri arasında tek başına kemoterapi planlanan hastalar çalışmaya dâhil edildi. Tıp fakültemizin Klinik Çalışmalar Etik Kurulu'ndan onay alındı (Sayı: 85252386-050.04.04). Sekizinci tümör-nodmetastaz (TNM-8) sınıflamasına göre evreleme yapıldı ${ }^{(5)}$. Çalışmaya katılmayı kabul eden hastalara gönüllü olur formu ve demografik form dolduruldu.

Çalışmaya lokal ileri ve metastatik akciğer kanseri tanısı ile tek başına kemoterapi planlanan, daha öncesinde cerrahi tedavi ya da radyoterapi almamış, 18 yaşından büyük hastalar dâhil edildi. Dışlama kriterleri ise; daha önce cerrahi tedavi veya radyoterapi almış olması, tanı anında kranial metastazı olması, akciğer dışı primer malignitesi olması, sistemik romatolojik ya da metabolik hastalığı olması, bilinen uyku bozukluğu tanısı olması, akciğer dışı organ yetmezliği olması, psikiyatrik hastalık ve ilaç kullanım öyküsü olması belirlendi. Üç kür kemoterapiyi tamamlayamayan, başka tedavi seçenekleri uygulanan, kemoterapi ajanı değiştirilen, tedaviyi terk eden veya kendi isteği ile çalışmadan ayrılmak isteyen hastaların çalışmadan çıkarılması planlandı. 
Demografik veri formunda çalışmaya dâhil edilen hastaların ad ve soyad, cinsiyet, yaş, doğum yeri, mesleği, sigara kullanımı, çevresel maruziyet öyküsü, aile öyküsü, ek hastalıkları, vücut kitle indeksi (BMI), performans durumu (ECOG), patolojik tanı, hastalık evresi, planlanan kemoterapi protokolü, tedavi yanıtı ve gereğinde iletişime geçmek için telefon numarası kaydedildi.

Tedavi planı yapıldığı gün ve 3. kür kemoterapi tamamlandıktan 3 . hafta sonra olmak üzere hastalara 2 kez uyku kalitesini değerlendirmek amacıyla "Pittsburg Uyku Kalitesi İndeksi" (PSQI) ve yaşam kalitesini değerlendirmek için de "Avrupa Kanser Tedavi ve Organizasyon Komitesi Yaşam Kalitesi Ölçeği” (EORTC QLQ-C30) uygulandı.

PSQI, 7 bölümden oluşmaktadır ve 1 aylık zaman aralığındaki uyku kalitesi ve bozukluğunu değerlendiren bir öz bildirim ölçeğidir. Toplam 24 sorudan oluşan ölçekte 19 soru kişi tarafından yanıtlanırken, 5 soru kişinin yatak arkadaşı tarafından yanıtlanmaktadır. Buysse ve ark. ${ }^{(6)}$ tarafından 1989 yılında geliştirilmiş ve yeterli iç tutarlılığa (Cronbach alfa $=0.80$ ), test-tekrar test güvenilirliğine ve geçerliliğe sahip olduğu gösterilmiştir. Ülkemizde PSQI'nin geçerlik ve güvenirlik çalışması Ağargün ve ark. ${ }^{(7)}$ tarafından yapılmıştır. Bu çalışmada, ölçeğin Cronbach alfa değeri 0.79 olarak bulunmuştur.

PSQI değerlendirmesinde; 1. bölümde subjektif uyku kalitesi, 2. bölümde uykuya geçme süresi, 3. bölümde uyku süresi, 4 . bölümde uyku effektivitesi, 5 . bölümde uykuyu etkileyen durumlar, 6. bölümde uyku verici madde kullanımı, 7. bölümde ise gün içinde uyuklama değerlendirilmektedir. Ölçeğin her alanı 0-3 arasında değişen ayrı puan olarak hesaplanmaktadır. Bu testin değerlendirmesi sırasında her bölüm içerisinde puan sistemi ile değerlendirme yapılabil- mekte ve ayrıca genel puan sistemi ile değerlendirme yapılmaktadır. Toplam değer 0-21 arasında bir puandır. Yüksek puanlar uyku kalitesinin bozuk olduğunu göstermektedir. Sıfır-beş puan sağlıklı uyku; 6-10 puan kötü uyku; 10 puanın üstü ise uzun dönem uyku rahatsızlığı ile uyumlu bulunmaktadır.

EORTC QLQ-C30 Yaşam Kalitesi Ölçeği, Avrupa Kanser Tedavi ve Organizasyon Komitesi (European Organisation for Research and Treatment of Cancer) tarafından geliştirilmiştir ${ }^{(8)}$. Toplamda 30 sorudan oluşmaktadır. Fonksiyonel Ölçek, Genel Sağlık Durumu Ölçeği ve Semptom Ölçeği olarak toplamda üç ölçekten oluşmaktadır. Fonksiyonel Ölçek fiziksel, rol, bilişsel, duygusal, sosyal alt boyutlarından; Genel Sağlık Durumu Ölçeği 29. ve 30. sorulardan; Semptom Ölçeği ise yorgunluk, bulantı ve kusma, ağrı, dispne, uyku bozukluğu, iştahsızlık, konstipasyon, diyare ve mali etki alt boyutlarından oluşmaktadır. Toplam puan alınabildiği gibi ana ölçeklerin alt boyutlarının da ayrı puan hesaplaması yapılabilmektedir.

Fonksiyonel ölçeklerden alınan yüksek puan sağlıklı fonksiyonel düzeyi; genel sağlık durumu ölçeğinden alınan yüksek puan yüksek yaşam kalitesini; semptom ölçeğinden alınan yüksek puan ise semptomların yoğun yaşandığını ve sorun düzeyinin yüksek olduğunu göstermektedir. Fonksiyonel ölçeklerden alınan "100" puan en iyi fonksiyon kapasitesini; “0” puan en düşük fonksiyon kapasitesini, genel sağlık durumu ölçeğinden alınan “100” puan en iyi sağlık durumunu; "0" puan en kötü sağlık durumunu, semptom ölçekleri açısından değerlendirildiğinde ise "0" puan en az semptom yükünü; “100” puan ise en çok semtom yükünü göstermektedir. Ölçeğin Türkçe geçerlik ve güvenirliği Güzelant ve ark. ${ }^{(9)}$ tarafından yapılmıştır ve Cronbach alfa katsayısı $\geq 0.70$ olarak bulunmuştur. 
Çalışmada elde edilen veriler "SPSS Statistics 21.0" programı ile istatistiksel olarak değerlendirildi. Tanımlayıcı istatistikler olarak frekans, yüzde değerler, ortanca (çeyrekler arası açıklık), ortalama ve standart sapma değerleri belirlendi. Karşılaştırmalardaki sayısal değişkenler normal dağılıma uymaktaydı. Bu değişkenler için Student t-test kullanıldı. Kategorik değişkenler arasındaki karşılaştırmalar ki-kare testi ile yapıldı. Mortaliteyi etkileyen değişkenlerin belirlenmesinde karşılaştırmalı korelasyon analizleri (Pearson) yapıldı. Bu istatistiksel hesaplamalarda $\mathrm{p}<0.05$ istatistiksel olarak anlamlı kabul edildi.

Çalışmaya dâhil edilme kriterlerini karşılayan ve çalışmaya katılmayı onaylayan 59 hasta, tedavi planı yapıldığı gün akciğer kanserinin uyku ve yaşam kalitesi üzerine etkileri açısından kesitsel olarak değerlendirildi ve kemoterapi sonrası değişiklikler açısından takibe alındı. Takibe alınan hastalar arasından 5 hasta performansta bozulma nedeniyle kemoterapinin kesilmesi; 7 hasta radyoterapi veya cerrahi tedavi değişikliği; 6 hasta takip dışı kalması; 3 hasta böbrek fonksiyon bozukluğu nedeniyle tedavinin yarıda kesilmesi; 1 hasta da erken progresyon nedeniyle tedavinin değiştirilmesi nedenleriyle olmak üzere toplam 22 hasta takipten çıkarıldı. Üç kür kemoterapiyi tamamlayan 37 hasta ise kemoterapinin erken dönemde uyku ve yaşam kalitesi üzerine

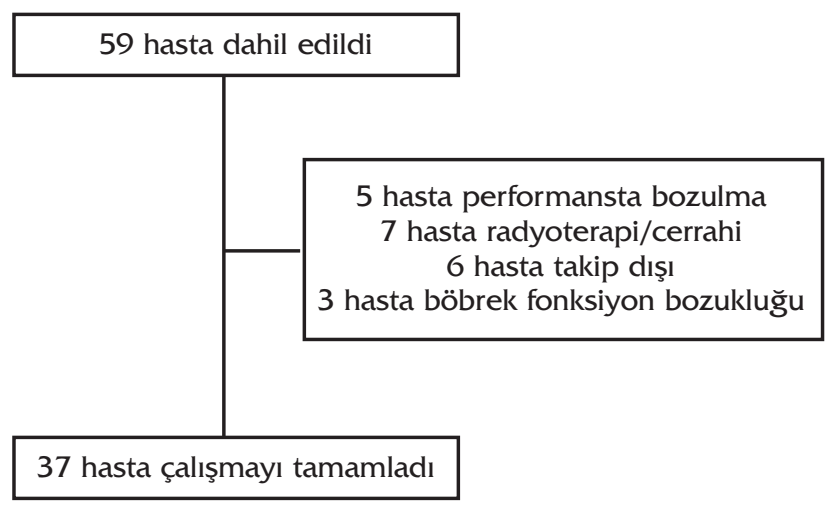

Şekil 1. Akış şeması. etkileri açısından prospektif olarak değerlendirildi (Şekil 1).

\section{BULGULAR}

Çalışmaya toplamda 59 hasta dâhil edildi. Çalışmaya alınan hastaların 6'sı kadın (\%10.2), 53'ü erkekti (\%89.8). Ortalama yaş 61.85 ( \pm 6.80$)$ olarak saptandı. Tüm hastalarda sigara içme öyküsü vardı ve ortalama sigara kullanım miktarı 48.83 ( \pm 30.59 ) paket-yıl idi. Yirmi üç hasta skuamoz hücreli karsinom (\%39.0), 17 hasta küçük hücreli akciğer karsinomu (\%28.8), 12 hasta adenokarsinom (\%20.3), 7 hasta ayrımı net yapılamayan küçük hücreli dışı akciğer karsinomu (\%11.9) tanılarına sahipti. TNM 8 evrelemesine göre hastaların 20'si evre 3B (\%33.9), 4'ü evre 3C (\%6.8), 20'si evre 4A (\%33.9), 15’i evre 4B (\%25.4) idi. Hastaların tanı anında yalnızca 18'i $(\% 30,5)$ iyi uyku kalitesine sahipken, 41'inin $(\% 69,5)$ uyku kalitesi kötüydü (Tablo 1$)$.

Çalışmaya alınan tüm hastaların tanı anındaki uyku ve yaşam kalitesi parametreleri incelendi. Hastaların uyku kalitesi belirgin olarak bozulmuştu ve PSQI ortalamaları $7.41 \quad( \pm 4.09)$ olarak

Tablo 1. Demografik veriler.

\begin{tabular}{lc}
\hline Cinsiyet & $\begin{array}{c}\% 89.8 \text { erkek } \\
\% 10.2 \text { kadın }\end{array}$ \\
\hline Yaş & $61.85( \pm 6.80)$ \\
\hline Sigara & $48.83( \pm 30.59)$ \\
\hline Evre & $3 B \% 33.9$ \\
& $3 C \% 6.8$ \\
& 4 A $\% 33.9$ \\
\hline Performans durumu $\% 25.4$ \\
\hline Uyku kalitesi & ECOG 0: $\% 45.8$ \\
& ECOG $1: \% 50.8$ \\
& ECOG $2: \% 3.4$ \\
\hline
\end{tabular}


Tablo 2. Tedavi öncesi uyku ve yaşam kalitesi parametreleri.

\begin{tabular}{lc}
\hline & Ortalama \\
& $7.41 \pm 4.09$ \\
Uyku kalitesi & $57.91 \pm 25.21$ \\
Genel yaşam kalitesi & $67.82 \pm 24.62$ \\
Fiziksel işlev & $73.30 \pm 22.69$ \\
Duygusal işlev & $75.65 \pm 28.74$ \\
Genel işlev & $83.33 \pm 22.32$ \\
Zihinsel işlev & $81.58 \pm 23.91$ \\
Sosyal işlev & $33.33 \pm 27.85$ \\
Ağrı & $15.82 \pm 27.93$ \\
Bulantı-kusma & $45.00 \pm 29.79$ \\
Halsizlik & $40.11 \pm 38.05$ \\
Dispne & $38.41 \pm 34.36$ \\
Uykusuzluk & $29.38 \pm 32.21$ \\
İstah kaybı & $24.86 \pm 33.67$ \\
Kabızlık & $4.52 \pm 14.46$ \\
İshal & $23.16 \pm 31.11$ \\
Maddi zorluk & \\
\hline
\end{tabular}

hesaplandı. Hastalar yaşam kalitesi skorları açısından değerlendirildiğinde, fonksiyon parametreleri arasında en çok fiziksel işlevin etkilendiği saptandı (67.82 \pm 24.62$)$. Yaşam kalitesini en çok bozan semptomlar ise hâlsizlik (\%45.00) ve dispneydi (\%40.11) (Tablo 2).

Hastaların tanı anındaki uyku kalitesi ile yaşam kalitesi parametreleri arasındaki ilişki araştırıldığında belirgin korelasyon saptandı. l̇yi uyku kalitesi olan hastalarda; genel yaşam kalitesi, fiziksel işlev, duygusal işlev, zihinsel işlev, sosyal işlev ve genel işlev skorları da iyi saptandı. Kötü uyku kalitesine sahip hastalarda ise ağrı, hâlsizlik, dispne, iştah kaybı, bulantı-kusma semptomları ve maddi zorluk anlamlı olarak fazlaydı (Tablo 3). Uyku kalitesi ile ishal ve kabızlık arasında ise anlamlı ilişki saptanmadı.

Çalışmayı tamamlayan 37 hastanın 4'ü kadın (\%10.8), 33'ü erkekti (\%89.2). Ortalama yaşları $62.35( \pm 5.94)$ olarak saptand kullanım miktarı $47.86( \pm 29.35)$ paket-yıldı. On üç hasta skuamoz hücreli karsinom (\%35.1), 11 hasta adenokarsinom (\%29.7), 10 hasta küçük hücreli akciğer karsinomu (\%27.0), 3 hasta ayrımı net yapılamayan küçük hücreli dışı akciğer
Tablo 3. Uyku kalitesi ve yaşam kalitesi parametreleri arasındaki iliş̧ki.

\begin{tabular}{lcc}
\hline & Uyku Kalitesi & \\
\hline & $(\mathbf{r})$ & (p) \\
\hline Genel yaşam kalitesi & -0.490 & 0.002 \\
Fiziksel işlev & -0.499 & 0.002 \\
Duygusal işlev & -0.418 & 0.010 \\
Genel işlev & -0.619 & $<0.001$ \\
Zihinsel işlev & -0.395 & 0.015 \\
Sosyal işlev & -0.471 & 0.003 \\
Ağrı & 0.588 & $<0.001$ \\
Bulantı-kusma & 0.382 & 0.019 \\
Halsizlik & 0.607 & $<0.001$ \\
Dispne & 0.366 & 0.026 \\
İstah kaybı & 0.427 & 0.008 \\
Maddi zorluk & 0.435 & 0.007 \\
\hline
\end{tabular}

karsinomu (\%8.1) idi. TNM 8 evrelemesine göre hastaların 10'u evre 3B (\%27.0), 4'ü evre 3C (\%10.8), 13'ü evre 4A (\%35.1), 10'u evre 4B (\%27.0) olup, 15 hastaya sisplatin-gemsitabin (\%40,5), 12 hastaya karboplatin-gemsitabin (\%32.4), 5 hastaya sisplatin-etoposid (\%13,5), 5 hastaya da karboplatin-etoposid $(\% 13,5)$ kemoterapisi verilmiştir. Üç kür kemoterapi sonrası yapılan yanıt değerlendirmesinde 24 (\%64.9) hastada düzelme, 7 (\%18.9) hastada ilerleme görüldü. 6 (\%16.21) hastanın da üç kür kemoterapi sonrasında stabil kaldığı saptandı.

Kemoterapi alan tüm hastalar karşılaştırıldığında; tedavi öncesi ortalama PSQI skoru 7.03 $( \pm 4.28)$ ve tedavi sonrası PSQI skoru $6.59( \pm 4.85)$ olarak saptandı. Tedavi öncesi ve sonrası arasında uyku kalitesi açısından anlamlı olarak farklılık saptanmadı $(p=0.62)$. Uyku kalitesindeki değişiklik kemoterapiye verilen yanıta göre incelendiğinde de anlamlı farklılık izlenmedi. Kemoterapi sonrası hastalığı progresyon veya regresyon gösterenlerde ve stabil seyredenlerde uyku kalitesi benzerdi $(p=0.67)$.

Hastaların tedavi öncesi ve sonrası yaşam kalitesi parametreleri karşılaştırıldığında; genel 
Tablo 4. Kemoterapi öncesi ve sonrası değişkenler.

\begin{tabular}{lccc}
\hline & Kemoterapi Öncesi & Kemoterapi Sonrası & p \\
\hline Uyku kalitesi & $7,03 \pm 4.28$ & $6.59 \pm 4.85$ & 0.62 \\
Genel yaşam kalitesi & $59.46 \pm 28.13$ & $60.59 \pm 25.96$ & 0.84 \\
Fiziksel işlev & $68.83 \pm 23.26$ & $62.34 \pm 24.20$ & 0.13 \\
Duygusal işlev & $77.93 \pm 20.99$ & $72.97 \pm 25.64$ & 0.19 \\
Genel işlev & $78.38 \pm 30.65$ & $72.52 \pm 31.23$ & 0.30 \\
Zihinsel işlev & $85.13 \pm 21.08$ & $82.43 \pm 22.20$ & 0.54 \\
Sosyal işlev & $83.78 \pm 23.40$ & $74.32 \pm 27.38$ & 0.053 \\
Ağrı & $32.43 \pm 27.20$ & $33.33 \pm 32.63$ & 0.87 \\
Bulantı-kusma & $16.22 \pm 30.80$ & $27.03 \pm 28.69$ & 0.053 \\
Halsizlik & $38.73 \pm 29.70$ & $53.15 \pm 39.99$ & 0.016 \\
Dispne & $40.54 \pm 42.41$ & $42.34 \pm 37.39$ & 0.81 \\
Uykusuzluk & $38.72 \pm 34.71$ & $37.84 \pm 39.41$ & 0.90 \\
İştah kaybı & $27.03 \pm 34.99$ & $27.03 \pm 28.15$ & 0.99 \\
Kabızlık & $19.82 \pm 31.88$ & $27.03 \pm 33.18$ & 0.30 \\
İshal & $3.60 \pm 13.11$ & $8.11 \pm 18.27$ & 0.25 \\
\hline
\end{tabular}

yaşam kalitesi, fiziksel işlev, duygusal işlev, genel işlev ve zihinsel işlev ile kemoterapi yanıtı arasında ilişki saptanmadı. Sosyal işlevler kemoterapi öncesi $83.78( \pm 23.40)$; kemoterapi sonrası 74.32 (27.38) olarak saptandı. Sosyal işlevler açısından kemoterapi sonrası kötüleşme gelişmiş olup, istatistiksel olarak zayıf ilişki vardı $(p=0.53)$. Kemoterapinin ağrı, dispne, uykusuzluk, iştah, kabızlık ve ishal üzerine etkisi saptanmadı. Bulantı-kusma skoru kemoterapi öncesi $16.22( \pm 30.80)$ ve kemoterapi sonrası $27.03( \pm 28.69)$ idi. Kemoterapi ile bulantıkusma semptomları arasında istatistiksel olarak zayıf ilişki saptandı $(p=0.53)$. Halsizlik skoru kemoterapi öncesinde $38.73( \pm 29.70)$ iken, sonrasında 53.15 ( \pm 39.99$)$ 'e yükseldiği gözlendi ( $p=0.016$ ) (Tablo 4).

Olguların patolojik tanısı, tanı anındaki hastalık evresi ve kemoterapiye verilen yanıtın uyku ve yaşam kalitesi parametrelerine etkisi açısından değerlendirildiklerinde anlamlı bir ilişki saptanmadı. Tedavi öncesi performans durumları açısından karşılaştırıldıklarında, performans durumu iyi olan hastalarda 3 kür kemoterapi sonrası bulantı-kusma semptomları belirgin olarak artarken, performans durumu daha kötü olanlarda bu semptomlarda düzelme izlendi $(p=0.042)$.

\section{TARTIŞMA}

Akciğer kanserli hastalarda uyku ve yaşam kalitesini etkileyecek bir çok etken birlikte bulunabilir. Ülkemizde akciğer kanserli hastalarda uyku kalitesi ile ilgili az sayıda veri mevcuttur. Akciğer kanserli hastalarda Pittsburg Uyku Kalitesi İndeksi ve akciğer kanserine özgü EORTC yaşam kalitesi anketlerinin kullanılarak uyku kalitesinin araştırıldığı bir literatür verisine rastlanmamıştır. Çalışmamız akciğer kanseri tanısı alan hastalarda uyku bozukluğunun sıklığını, uyku kalitesinin yaşam kalitesi parametreleri ile ilişkisini ve kemoterapi sonrası erken dönemde uyku ve yaşam kalitesi üzerindeki değişimleri göstermiştir.

Çalışmamızda, kemoterapi öncesi değerlendirme yapıldığında, uyku kalitesini etkileyecek başlıca hastalıklar dışlama kriteri kabul edilmesine rağmen akciğer kanserli hastaların çoğunda uyku kalitesinin kötü olduğu görülmektedir. Bu durum akciğer kanserinin sistemik etkilerine, hastaların ileri yaş grubunda olmasına ve ortak 
komorbiditelere bağlı olabilir. Akciğer kanserli hastalarda uyku kalitesi yaşam kalitesi ile belirgin olarak ilişkili bulunmuştur. Bu hasta grubunda uyku kalitesi ile ilgili önlemlerin ve gereken olgularda tedavilerin yaşam kalitesi ve prognoz üzerine olumlu etkileri olabilir. Akciğer kanserli hastalarda yaşam kalitesinin prognozu öngörebildiği de belirtilmektedir ${ }^{(10)}$.

Üç kür kemoterapi sonrası erken dönemde yaşam kalitesi fonksiyonel parametrelerinden sosyal işlev; semptom parametrelerinden hâlsizlik ve bulantı-kusma daha kötü olarak saptandı. Bu sonuçlar kemoterapinin doğrudan yan etkileri ile açılanabilmektedir. Kemoterapi öncesi performans durumu kötü olan hastalarda ise bulantı-kusma semptomunun düzelmiş olması; genel sağlık durumu kötü olan hastalarda kemoterapi ile düzelmenin kemoterapiye bağlı yan etkilerin önüne geçtiğini düşündürmektedir. Hastaların diğer yaşam kalitesi parametreleri ve uyku kalitesinde ise belirgin değişme saptanmamıştır.

Kanser hastalarında uyku bozuklukları sık görülmekle birlikte, altta yatan hastalığın ciddiyeti nedeniyle hastaların ve hekimlerin dikkatinden kaçabilmektedir. Kanser hastalarında genel olarak insomni, kötü uyku kalitesi, uykuya dalmakta güçlük gibi çeşitli uyku bozuklukları \%3-67 oranında bildirilmiştir ${ }^{(11)}$. Ülkemizde bu konuda çok az sayıda veri vardır. Gelişken Akyüz, tez çalışmasında Visual Analog Skala-Ağrı, Visual Analog Skala-Uyku derecelendirmesi kullaılarak ileri evre akciğer kanserli hastalarda uyku durumu değerlendirilmiş, uyku kalitesini etkileyen etmenlerin belirlenmesi ve ortadan kaldırılmasını önermiştir ${ }^{(12)}$. Albayrak'ın tez çalışmasında, 87 akciğer kanser hastasının \%26.4'ünde uykuya dalma ve sürdürme sorunu, \%35.6'sında sabah erken uyanıp uyuyamama, \%52.9'unda öğlen saatlerinde uyuklama ve \%52.9'unda hâlsizlik saptamıştır. Uykusuzluk yakınmasının ise \%54.9 oranında olduğunu belirtmiştir ${ }^{(13)}$. Kolon, meme ve akciğer kanserli hastaları inceleyen bir çalışmada, PSQI skoru ile değerlendirildiğinde hastalarda kötü uyku kalitesi oranı kemoterapi öncesi \%96.7 ve 6 kür kemoterapi sonrası $\% 100$ olarak saptanmıştır ${ }^{(14)}$.

Lou, ve ark. ${ }^{(15)} 128$ ileri evre akciğer kanseri hastasında, \%62,5 oranında uyku bozukluğu saptamış, solunum bozuklukları ve uyku bozukluğunun bu hastalarda yaşam kalitesini olumsuz etkilediğini belirtmiştir. Chang ve Lin uzun süre takip ettikleri akciğer kanseri hastalarında yaşam kalitesinin kötü uyku kalitesinden olumsuz etkilendiğini belirtmiştir ${ }^{(16)}$. Grutsch ve ark.'nın (17) çalışmalarında, 65 küçük hücreli dışı akciğer kanseri olgusunda sağlıklı popülasyona göre uyku kalitesi ve sirkadiyen ritmde belirgin bozulma saptanmıştır. Bu sonuçlar, çalışmamızın sonuçlarıyla benzeşmektedir.

Çalışmamızın başlıca kısıtlılıkları; çalışma protokolü gereği erken evredeki hastaların çalışmaya dahil edilememiş olması, kemoterapinin uyku ve yaşam kalitesine uzun dönem etkilerinin incelenememesi ve az sayıda hastayla yürütülmüş olmasıdır. Uyku ve yaşam kalitesini etkileyecek diğer başlıca faktörler dışlama kriteri sayılmasına rağmen, çalışmaya dâhil edilen hastaların ileri yaşta ve ileri evre kanser hastaları olmaları nedeniyle sonuçlar etkilenmiş olabilir.

\section{SONUÇ}

Akciğer kanserli hastaların çoğunda uyku kalitesi belirgin olarak bozulmuştur. Hastaların tanı anındaki uyku ve yaşam kaliteleri birbiriyle korelasyon göstermektedir. Akciğer kanserli hastalarda kemoterapi erken dönemde hastaların uyku kalitesinde belirgin bir değişiklik yapmıyorken yaşam kalitesini olumsuz yönde etkileyebilmek- 
tedir. Bu etkilenmenin kemoterapinin özellikle hâlsizlik, bulantı-kusma yakınmalarını arttırması ve sosyal işlevleri azaltması ile ilişkili olduğu düşünülmektedir.

Uyku ve yaşam kalitesi arasındaki belirgin ilişki nedeniyle, akciğer kanserli hastaların tanı anında uyku kalitesi ve bozuklukları açısından değerlendirilmesi ve gerektiğinde tedavisi hastaların yaşam kalitesinin düzelmesini sağlayacaktır. Daha geniş hasta gruplarını içeren ve kanser tedavisi ile eşzamanlı uyku bozukluğuna yönelik tedavileri araştıran çalışmalara gereksinim vardir.

Etik Kurul Onayı: Manisa Celal Bayar Üniversitesi Klinik Araştırmalar Etik Kurulu'ndan onay alınmıştır (15.10.2019/52, sayı: 85252386-050.04.04).

Çıkar Çatışması: Herhangi bir çıkar çatışması yoktur.

Finansal Destek: Finansal destek yoktur.

Hasta Onamı: Alınmıştır.

Ethics Committee Approval: Approval was obtained from Manisa Celal Bayar University Clinical Research Ethics Committee (15.10.2019/52, number: 85252386-050.04.04).

Conflict of Interest: There is not any conflict of interest.

Funding: There is no financial support.

Informed Consent: Has been taken.

\section{KAYNAKLAR}

1. Yavuzşen T, Alacacıoğlu A, Çeltik A, Yılmaz U. Kanser ve uyku bozuklukları. Türk Onkoloji Dergisi 2014;29(3): 112-9.

2. Göktalay T, Akın M, Aydemir Ö. Akciğer kanserli hastalarda yaşam kalitesi değerlendirilmesi. Solunum Hastalıkları 2002;13:265-70.

3. Polanski J, Jankowska-Polanska B, Rosinczuk J, Chabowski M, Szymanska-Chabowska A. Quality of life of patients with lung cancer. OncoTargets and Therapy 2016;9:1023-8.

https://doi.org/10.2147/OTT.S100685
4. Daroszewski C, Stasiewicz M, Jazwinska-Tarnawska E, Rachwalik A, Mura E, Luboch-Kowal J, et al. Quality of Life in Patients with Advanced Non-Small-Cell Lung Cancer Receiving Palliative Chemotherapy. Advances in Experimental Medicine and Biology 2019;1160:11-8. https://doi.org/10.1007/5584_2019_346

5. Brierley JD, Gospodarowicz MK, Wittekind C eds. TNM Classification of Malignant Tumours, 8th Edition. International Union Against Cancer (UICC). WileyBlackwell; 2017.

https://doi.org/10.1002/9780471420194.tnmc26. pub3

6. Buysse D, Reynolds C, Monk T, Berman SR, Kupfer DJ. The Pittsburgh Sleep Quality İndex: A New İnstrument For Psychiatric Practice And Research. Psychiatry Research 1989;28(2):193-213. https://doi.org/10.1016/0165-1781(89)90047-4

7. Ağargün MY, Kara H, Anlar Ö. Pittsburgh Uyku Kalitesi İndeksi'nin Geçerliği ve Güvenirliği. Türk Psikiyatri Dergisi 1996;7(2).

8. Bergman, B., Aeronson, N., Ahmedzai, SH., Kaasa, S., and Sullivan, M. The EORTC QLQ-LC13: A Modular Supplement to The EORTC Core Quality of Life Questionnaire (QLQ-C30) for Use in Lung Cancer Trials. EORTC Study Group on Quality of Life. Eur J. Cancer 1994;30A(5) 635-42.

https://doi.org/10.1016/0959-8049(94)90535-5

9. Güzelant A, Göksel T, Ozkok S, Aysan T, Bottomley A. The European organization for research and treatment of cancer QLQ C-30: An Examination into the culturel validity and reliability of Turkish version Of QLQ-C-30. European Journal Of Cancer Care 2004;13(2):135-44. https://doi.org/10.1111/j.1365-2354.2003.00435.x

10. Eser S, Göksel T, Erbaycu AE, Baydur H, Başarık B, Öz Yanık A, Kıyar Gürsul K, et al. Comparison of generic and lung cancer specific quality of life instruments for predictive ability of survival in patients with advanced lung cancer. Springer Plus 2016;5:1833.

https://doi.org/10.1186/s40064-016-3492-7

11. Moens KJ. Are there differences in the prevalence of palliative care-related problems in people living with advanced cancer and eight non-cancer conditions? A systematic review. Pain Symptom Manage 2014;48(4): 660-7.

https://doi.org/10.1016/j.jpainsymman.2013.11.009

12. Gelişken Akyüz R. İleri evre akciğer kanserli hastalarda uyku kalitesi ve etkileyen etmenlerin incelenmesi. Yüksek Lisans Tezi. İzmir: Dokuz Eylül Üniversitesi Sağlık Bilimleri Enstitüsü; 2010.

13. Albayrak S. Akciğer kanserli olgularda uyku bozuklukları. Uzmanlık Tezi. İzmir: Dokuz Eylül Üniversitesi; 2006.

14. Pazarcıkçı F. Kemoterapi alan kanser hastalarında uyku kalitesinin değerlendirilmesi. Mehmet Akif Ersoy 
Üniversitesi Sağlık Bilimleri Enstitüsü Dergisi 2017;5(1):11-21.

https://doi.org/10.24998/maeusabed.292260

15. Lou VWQ, Chen EJ, Jian H, Zhou Z, Zhu J, Li G, He Y. Respiratory symptoms, sleep, and quality of life in Patients With Advanced Lung Cancer. Journal of Pain and Symptom Management 2017;53:2.

https://doi.org/10.1016/j.jpainsymman.2016.09.006

16. Chang WP, Lin CC. Changes in the sleep-wake rhythm, sleep quality, mood, and quality of life of patients receiving treatment for lung cancer: A longitudinal study. Chronobiology International 2017;34(4):451-61. https://doi.org/10.1080/07420528.2017.1293678

17. Grutsch FC, Wood PA, Du-Quiton J, Reynolds JL, Lis CG, Levin $\mathrm{RD}$, et al. Validation of actigraphy to assess circadian organization and sleep quality in patients with advanced lung cancer. Journal of Circadian Rhythms 2011;9:4.

https://doi.org/10.1186/1740-3391-9-4 